Venny Veronica Natalia, Dirk Heinrichs

\title{
Identifying polycentricism: a review of concepts and research challenges
}

Journal article | Accepted manuscript (Postprint)

This version is available at https://doi.org/10.14279/depositonce-9597

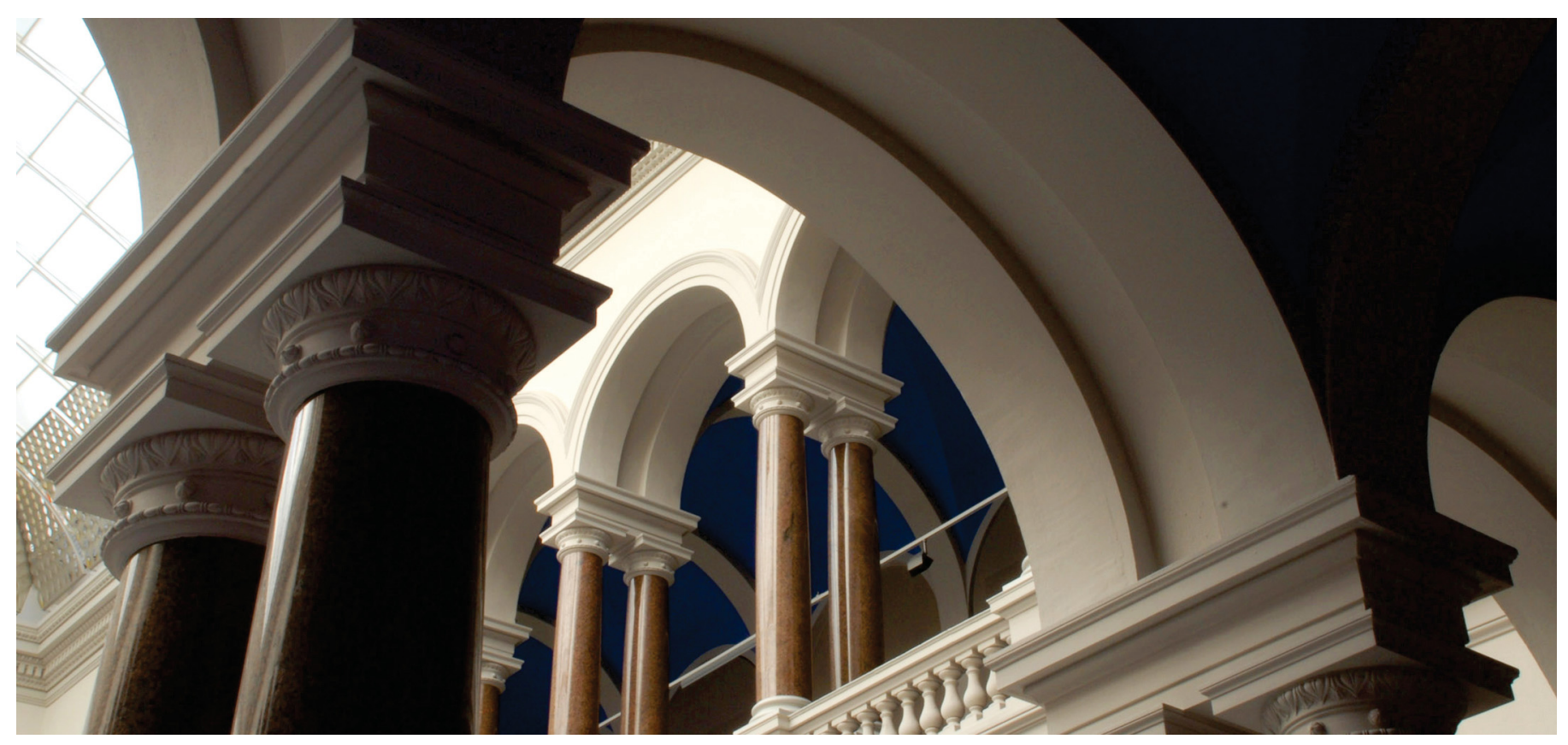

Natalia, V. V., \& Heinrichs, D. (2019). Identifying polycentricism: a review of concepts and research challenges. European Planning Studies, 1-19. https://doi.org/10.1080/09654313.2019.1662773 


\title{
Identifying Polycentricism: A Review of Concepts and Research Challenges
}

\author{
Venny Veronica Natalia ${ }^{1,2}$, Dirk Heinrichs ${ }^{3}$ \\ ${ }^{1}$ Institute of Urban and Regional Planning, Technische Universität Berlin; \\ natalia@campus.tu-berlin.de \\ ${ }^{2}$ Department of Urban and Regional Planning, Hasanuddin University, Indonesia \\ veronicanatalia@unhas.ac.id \\ ${ }^{3}$ Institute of Urban and Regional Planning, Technische Universität Berlin; \\ dirk.heinrichs@tu-berlin.de
}

\begin{abstract}
Assessment of polycentricism is one approach to understand the process of urban expansion and its structural changes. The assessment is important to provide knowledge as a basis for future planning and policy. This review article structures the existing concepts of polycentricism, examines the methodologies applied for polycentricism assessment at different spatial scales and across world regions. Based on this, it identifies future research challenges. The review shows that studies of polycentricism have been conducted primarily in cities across the more developed world regions of Europe and North America, while in the developing world regions, fewer studies are available and only began to emerge in the 1990s, two decades later than the West. The reviewed studies use employment distribution and travel behaviour as the primary sources of data. To compensate for the lack of well-documented employment distribution and mobility data, more diverse indicators and sophisticated digital-based approaches have been applied in the latest studies that focus on cities in developing world regions. The reviewed studies demonstrate for the examined cases a general shift towards polycentric development. While in the more developed world regions polycentricism is influenced by employment decentralization, in the developing world regions this phenomenon is influenced by market forces and spatial planning policies.
\end{abstract}

Keyword: polycentricism, urban centers, developed world, developing world, indicators.

\footnotetext{
"This is an [Accepted Manuscript / Original Manuscript] of an article published by Taylor \& Francis in [Identifying Polycentricism: A Review of Concepts and Research Challenges] on [04.09.2019], available at http://wwww.tandfonline. com/10.1080/09654313.2019.1662773.
} 


\section{Introduction}

Understanding urban spatial trends is essential to appropriately understand patterns and trends, such as, sprawl, automobile dependence, and land use inefficiency as well as to achieve better urban planning policies (Kloosterman \& Musterd, 2001; Veneri, 2015; Zhong, Huang, Arisona \& Schmitt, 2013). Since the beginning of spatial and functional decentralization in the nineteenth century, urban spatial structures have shifted from monocentric to polycentric forms and have continued to do so until today (McDonald \& McMillen, 1990; Newman \& Kenworthy, 2015; Riguelle, Thomas, Verhetsel, 2007). This fundamental change is described by Romein, Verkoren and Fernandez-Maldonado (2009) who observe that the Central Business District (CBD) ceased to be the only place of activities and jobs in a city. Based on the work of Davoudi (2003) and in line with You (2017), the shift has been caused by several factors, i.e. the rapid decentralization of economic activities, the increase in mobility due to new transport technology, such as, high-speed transport that gives people the opportunity to move further from urban to suburban areas or to other cities, the fragmentation of spatial distribution of activities, changes to household size and lifestyle, and a variety of travel patterns (cross-commuting).

Urban expansion is associated with the rise of new economic sub-centres that change the traditional monocentric structure. Many studies have shown empirical results that confirm that the monocentric form is no longer valid. A monocentric form is not suitable to describe the spatial arrangement of modern urban areas today. As a polycentric model increasingly reflects reality (Clark, 2000; Davoudi, 2003; McMillen, 2001; Romein et al., 2009), studies of the monocentric form have gradually decreased. Instead, the analysis has changed to focus on polycentric urban form (You, 2017).

Regarding polycentricism and urban centre identification, many studies have taken cities in 
the developed world as their case study (Davoudi, 2003) while only a few studies have been applied to the cities in the developing world (Yue, Liu, \& Fan, 2010). The process of decentralization in the developing world has occurred primarily in a spontaneous and widely unplanned fashion.

The aim of this paper is to discuss how studies on polycentric development have evolved and been implemented worldwide. Questions of particular interest include (1) what are the underlying concepts and contexts of application; (2) what approaches and indicators have been used so far; (3) what evidence do the studies show as to whether or not polycentric development is taking place; (4) what research challenges can be identified based on the achievements so far?

This article reviews the most frequently cited literature, i.e. scientific articles, reports and working papers on polycentricism that have been published over the past three decades. References were systematically searched through specific keywords: polycentricity, polycentric and urban centre identification. This search yielded a total of 55 documents that were then filtered. The selection criteria were that studies provide empirical evidence to assess polycentricism or to identify urban centres (employment or activity) based on a methodological procedure, data, and indicators. Furthermore, the findings of the study should provide evidence on the number of urban centres in the case study locations and/or the presence of polycentric or monocentric forms. A total of 20 studies complied with these criteria and were included in further analysis. The reviewed research can be divided into twelve articles at the intra-urban scale and eight articles at the inter-urban and nationalinternational scale. Thirty-five references were excluded from the sample. Most of them are reviews and comparative studies that were considered for supporting arguments in section four in particular. One methodological article was excluded because the applied methodology 
did not match the selection criteria. Rather than identifying centre(s) empirically, the research predetermined them and developed a method for their functional interaction. We included the study, however, as a source for the general discussion.

This article is divided into six sections. The following section, section two, describes polycentricism. The third section presents the approaches to polycentric assessment provided by the selected papers. The fourth section examines the results that the studies show with respect to urban spatial transformation. The fifth section provides a discussion that presents research challenges of the twenty reviewed studies as well as future research suggestions and challenges. Section six follows with a conclusion.

\section{Polycentricism: definitions, concepts and context of application}

The appearance of the concept of polycentricism has attracted the attention of many scholars in the field of urban planning, geography, public policy, and economics (Cai, Huang \& Song, 2017; Davoudi, 2003; Hoyler, Kloosterman \& Sokol, 2008). This interest demonstrates that the topic has essential value regarding its association with economics, urban physical structures as well as transportation. The popularity of polycentricism as a normative goal in spatial planning (Burgalassi, 2010) has made it an important topic to be explored further in research on today's dynamic urban form.

A measure of functional and morphological polycentricism is important to have a deep understanding of polycentric form and its spatial processes (Schmitt, Volgmann, Münter \& Reardon, 2015; Vasanen, 2012). The main factors of the morphological dimension include (1) clustering of separate centres and (2) size and spacing of centres. The functional dimension considers the economic specialization and the interaction among centres (Burgalassi, 2010).

A precise operational definition of the concept of polycentricism remains in debate (Wegener, 
2013) as the notion of polycentricism has been applied at different spatial scales (Burgalassi, 2010). Scholars have formulated three spatial scales at which the concept has been applied. The first is the 'meso' level that focuses on the cluster of people and economic activity inside a city (intra-urban, for example, Los Angeles, Paris, and London). The second is the 'macro' level that focuses on defining multiple centres in a region (inter-urban scale, for example, the West Coast of America or the North-west of Europe, Dutch Randstad). The third is the 'mega' level that focuses on the larger spatial scale, to the core-periphery in national or international spatial structure, for example, the European territory. Some scholars argue that clear measurements need to be established (Amindarbari \& Sevtsuk, 2013; Davoudi, 2003; Kloosterman \& Musterd, 2001).

Brezzi and Veneri (2014) summarize the objectives of polycentric assessment at different spatial scales. At the intra-urban scale, the objective is to improve the efficiency of land use, transport, and public service. At the inter-urban scale, the objective is to utilize the regional agglomeration and confront regional disparity. At the national-international scale, the objective is to design national policy, foster economic agglomeration, ensure policy coherence, and confront regional disparities.

Concerning cities as multidimensional spatial phenomena, polycentricism could refer to a process of spatial cluster formation whereby multiple centres exist in an area (Brezzi \& Veneri, 2014; Kloosterman \& Musterd, 2001; Riguelle et al., 2007). Polycentricism also refers to the strategic spatial planning tool or the changing of the urban spatial structure (Davoudi, 2003). Thus, polycentricism is a concept with various meanings that can refer to the physical form of urban spatial structure or to the contents and intention of normative spatial planning policy (Rauhut, 2017).

Debates have arisen and continue among researchers concerning the concept of 
polycentricism related to its actual benefit for various fields such as economics, transportation, and land use efficiency. Interaction in the polycentric urban configuration, without a sufficient public transport service, creates traffic problems due to the use of private vehicles (Burgalassi, 2010). Other findings reveal that polycentricism has various advantages, i.e. combating sprawl, promoting efficient public transport services, reducing commuting trips and traffic congestion, minimizing the distance between housing and job location (Cervero \& Wu, 1997; McMillen, 2001).

When referring to the inter-urban and national-international scale, the Commission of the European Union (1999) describes that implementing the concept of polycentricism is one strategic action to achieve sustainable spatial development. In contrast to polycentricism as an analytical concept (functional and morphological), it is here seen as a normative concept (Green, 2007). Polycentric development can reduce disparities, create balance, and maintain urban and rural diversity. The concept of polycentricism was introduced due to the unbalanced spatial structure and significant socio-economic differences between the regions and countries of Europe. However, polycentricism from the European Spatial Development Perspective (ESDP) is not easy to achieve because implementing the concept as part of development policy on a national scale requires enormous effort. The policy needs to be synchronized at the local authority level, and regarding this point, only a few participants in European countries are willing to support the efforts. However, according to Faludi (2004, 2005), the formation of transnational cooperation networks is one way to implement polycentricism as a territorial cohesion policy.

Gløersen, Lähteenmäki-Smith, and Dubois (2007) describe the complexity to implementing polycentricity as a planning initiative. Efforts have been made by forming two communities, i.e. ESPON and INTERREG, to support the implementation of polycentric policy at the 
national-international scale of European territory. ESPON has succeeded in gathering quantitative evidence of regional trends but has failed to measure the stakeholder role and potential impact of their intervention. On the other hand, INTERREG suggests a reinvented term of polycentricism to be able to adopt the policy in regional and local planning practices.

Despite the significant influence of polycentricism in spatial planning policy, the idea for achieving this goal is not supported by empirical results (Davoudi, 2003; Wegener, 2013). Most of the evidence shows an opposing result. For instance, Meijers and Sandberg (2006) support this argument by demonstrating that the more polycentric a national urban system is, the more disparities exist.

\section{Approaches to polycentric assessment}

This section is divided into two parts. The first part reviews studies based on their findings of sub-centres at the intra-urban scale. The second part reviews studies that provide approaches to polycentric assessment at the inter-urban and national-international scale.

The following definitions of an urban centre are used in the 20 reviewed studies. Most studies use the term 'sub-center' as a location that has higher employment density than other areas in the neighbourhood and is large enough to influence the urban structure, local population density, land prices and housing prices (McDonald 1987; McMillen, 2001).

Based on the observation that centres are urban attractors which generate travel of large populations carrying out various activities, such as, shopping, eating, and leisure (Zhong et al., 2013), a few other studies use the term 'activity center', this defines a location that has a high potential for trip generation (Gordon \& Richardson, 1996). 


\subsection{Intra-urban scale}

This section reviews studies regarding centre or sub-centre identification. This review section is needed because many researchers show various interpretations concerning the implication of sub-centre growth, and various types of measurement make it difficult to compare across polycentric studies (Cervero \& Wu, 1997). Each study has its own approach and indicators to identify polycentricism and urban centres. The evidence from eleven selected studies is summarized in Table 1.

Table 1. Summary of dominant studies in polycentric assessment at the intra-urban scale

\begin{tabular}{|c|c|c|c|c|c|c|}
\hline No & Author(s) & Year & Approaches & Indicators & Location & Findings \\
\hline 1 & McDonald & 1987 & $\begin{array}{l}\text { Sub-centre is identified by } \\
\text { the local peaks in gross } \\
\text { employment density and the } \\
\text { employment-population } \\
\text { ratio. }\end{array}$ & $\begin{array}{l}\text { Employment } \\
\text { density }\end{array}$ & Chicago & 44 zones \\
\hline 2 & $\begin{array}{l}\text { Giuliano \& } \\
\text { Small }\end{array}$ & 1991 & $\begin{array}{l}\text { Sub-centre is identified by } \\
\text { the peaks in the spatial } \\
\text { distribution of the population } \\
\text { or employment } \\
\text { threshold: } \\
10 \text { workers per acre and } \\
10,000 \text { employees per sub- } \\
\text { centre. } \\
\text { Later the results are } \\
\text { compared with } \\
\text { Transportation Analysis } \\
\text { Zones. }\end{array}$ & $\begin{array}{l}\text { Employment } \\
\text { density, } \\
\text { travel flows }\end{array}$ & $\begin{array}{l}\text { Los } \\
\text { Angeles }\end{array}$ & $\begin{array}{l}32 \text { centres } \\
\text { and } 5 \text { clusters }\end{array}$ \\
\hline 3 & $\begin{array}{l}\text { Gordon \& } \\
\text { Richardson }\end{array}$ & 1996 & $\begin{array}{l}\text { Sub-centre is identified by } \\
\text { computing trip generation } \\
\text { density in Transportation } \\
\text { Analysis Zones. }\end{array}$ & Trip densities & $\begin{array}{l}\text { Los } \\
\text { Angeles }\end{array}$ & $\begin{array}{l}\text { Number of } \\
\text { centres not } \\
\text { clearly } \\
\text { mentioned. } \\
\text { Los Angeles } \\
\text { region more } \\
\text { dispersed than } \\
\text { polycentric. } \\
\end{array}$ \\
\hline 4 & $\begin{array}{l}\text { Cervero \& } \\
\mathrm{Wu}\end{array}$ & 1997 & $\begin{array}{l}\text { As a start, sub-centres are } \\
\text { identified by their density } \\
\text { and size using a specific } \\
\text { threshold ( } 7 \text { workers per } \\
\text { gross acre). A centre must } \\
\text { amount to at least } 10,000 \\
\text { workers. Subsequently, } \\
\text { commute times, modal splits, } \\
\text { and rates of internal } \\
\text { commuting among } \\
\text { employment centre classes } \\
\text { are then compared. }\end{array}$ & $\begin{array}{l}\text { Employment } \\
\text { density, } \\
\text { commuting } \\
\text { times, } \\
\text { modal splits, } \\
\text { rates of internal } \\
\text { commuting }\end{array}$ & $\begin{array}{l}\text { San } \\
\text { Francisco } \\
\text { Bay Area }\end{array}$ & 22 centres \\
\hline
\end{tabular}




\begin{tabular}{|c|c|c|c|c|c|c|}
\hline No & Author(s) & Year & Approaches & Indicators & Location & Findings \\
\hline 5 & $\begin{array}{l}\text { McMillen } \\
\& \\
\text { McDonald }\end{array}$ & 1998 & $\begin{array}{l}\text { First, potential sub-centres } \\
\text { are identified with specific } \\
\text { thresholds ( } 20 \text { employees per } \\
\text { acre, and } 20,000 \text { employees } \\
\text { per sub-centre). Second, Bid- } \\
\text { rent model is performed to } \\
\text { increase the accuracy of the } \\
\text { result in the first step } \\
\text { (differentiate zones that } \\
\text { contain employment and } \\
\text { those that do not). The } \\
\text { analysis includes } \\
\text { accessibility measures as } \\
\text { explanatory variables. }\end{array}$ & $\begin{array}{l}\text { Employment } \\
\text { density, } \\
\text { distance to CBD, } \\
\text { distance to rail } \\
\text { system, } \\
\text { distance to } \\
\text { stations, } \\
\text { distance to } \\
\text { highway } \\
\text { interchange }\end{array}$ & Chicago & $\begin{array}{l}20 \text { identified } \\
\text { sub-centres }\end{array}$ \\
\hline 6 & Craig \& Ng & 2001 & $\begin{array}{l}\text { Sub-centres are identified by } \\
\text { using a quantile regression } \\
\text { approach and employment } \\
\text { gradient. }\end{array}$ & $\begin{array}{l}\text { Employment } \\
\text { density } \\
\text { Distance to CBD }\end{array}$ & Houston & $\begin{array}{l}7 \text { employment } \\
\text { sub-centres }\end{array}$ \\
\hline 7 & McMillen & 2001 & $\begin{array}{l}\text { Potential sub-centre is } \\
\text { identified with locally } \\
\text { weighted regression. } \\
\text { Regression analysis is } \\
\text { applied to assess the } \\
\text { significance of the potential } \\
\text { sub-centre. }\end{array}$ & $\begin{array}{l}\text { Employment } \\
\text { density } \\
\text { Distance to CBD }\end{array}$ & Milwaukee & $\begin{array}{l}\text { One suburban } \\
\text { sub-centre. } \\
\text { Milwaukee is } \\
\text { still primarily a } \\
\text { monocentric } \\
\text { city. }\end{array}$ \\
\hline 8 & Yue, et al. & 2010 & $\begin{array}{l}\text { Spatial analysis in urban- } \\
\text { rural gradient and growth } \\
\text { type. }\end{array}$ & $\begin{array}{l}\text { Footprint of } \\
\text { construction } \\
\text { land, cultivated } \\
\text { land, forest, and } \\
\text { water }\end{array}$ & $\begin{array}{l}\text { Hangzhou, } \\
\text { China }\end{array}$ & 4 zones \\
\hline
\end{tabular}

Flow matrix is used to

describe the flow

distribution.

Hierarchical clustering method is used to aggregate

9 Roth, et al. 2011 all stations within a distance of $1-2 \mathrm{~km}$ to gather the geographical proximity of groups of stations which the results defined as activity centres.
Passenger mobility pattern based on Oyster London 10 centres transportation card
Detecting the urban spatial

10 Zhong, et al.

2013 structure using a centrality index and attractiveness indices.

Sub-centre is identified by a

Fernandez-

11 Maldonado, 2014 et al. specific threshold in Giuliano

\& Small, 1991:

10 workers per acre and 10,000 employees per subcentre.
5 first-level centre in 2004

Trip purposes Singapore and

4 first-level centre in 2008

Employment City, in Mexico City
number Mexico 30 sub-centres Employment Lima, Peru in Lima density

Fortaleza, 11 sub-centres Brazil in Fortaleza 


\begin{tabular}{|c|c|c|c|c|c|c|}
\hline No & Author(s) & Year & Approaches & Indicators & Location & Findings \\
\hline 12 & Cai, et al. & 2017 & $\begin{array}{l}\text { Main centres are located } \\
\text { using cluster analysis (Local } \\
\text { Moran's I). } \\
\text { Sub-centre candidates are } \\
\text { selected using significant } \\
\text { positive residuals from } \\
\text { geographically weighted } \\
\text { regression (GWR). } \\
\text { Final centres are filtered } \\
\text { using the global natural } \\
\text { breaks classification (NBC). }\end{array}$ & 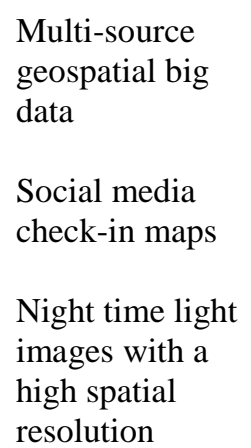 & $\begin{array}{l}\text { Beijing, } \\
\text { Shanghai, } \\
\text { and } \\
\text { Chongqing }\end{array}$ & $\begin{array}{l}9 \text { sub-centres in } \\
\text { Beijing } \\
12 \text { sub-centres } \\
\text { in Shanghai } \\
8 \text { sub-centres in } \\
\text { Chongqing }\end{array}$ \\
\hline
\end{tabular}

In his milestone study on Chicago, McDonald (1987) proposes experimental procedures to identify urban sub-centres based on the employment-population ratio. He defines the subcentre as the second peak outside the CBD (using "journey to work" survey data), as well as local peaks in gross employment density and the employment-population ratio indicators. McDonald finds that, in general, the employment-population ratio will decline with the distance to the CBD. However, he finds a negative coefficient in the sub-centre near O'Hare Airport which has 12.5 miles distance to the CBD. The employment-population ratio is as high as the sub-centre with the closest distance to the CBD (0 miles). The McDonald study reveals that sub-centre establishment is influenced by the ratio of employment-population, distance to $\mathrm{CBD}$, and distance to transportation facilities (node and network). On the other hand, Giuliano and Small (1991) correctly underline the study's limitation, whereby the size of each zone was not explicitly described. Moreover, Amindarbari and Sevtsuk (2013) argue that this approach fails to explain the spatial fact that joining areas together has the potential to create a higher peak of employment than the CBD based on their spatial cluster boundary.

Studies that combine the perspectives of an urban planner and economist were conducted by Giuliano and Small (1991) in the case of the city of Los Angeles. In agreement with McDonald (1987), they provide a simple definition of the sub-centre based on its gross 
employment density and total employment. Using journey-to-work data, this study reveals information related to the sub-centre's size and also provides insight into the economic agglomeration associated with congestion. Based on their specific thresholds, Giuliano and Small (1991) identify 32 centres. Even though many further studies use this threshold to identify potential sub-centres, others argue that this cut-off is subjective and cannot simply be applied to a different case (Huang Liu, \& Zhao, 2015; McMillen \& McDonald, 1998; McMillen, 2001; Riguelle et al., 2007).

Based on the study at the inter-regional scale, Riguelle et al. (2007), suggest that spatial autocorrelation is more suitable than the cut-off method and does not require full knowledge of the study area. On the contrary, Giuliano and Small (1991), use hierarchical cluster analysis. They define 32 centres and 5 clusters (specialized manufacturing, mixed industrial, mixed service, specialized entertainment, and specialized service), describing that the subcentre is established not solely by the number of employees.

The research of Gordon and Richardson (1996) also took the city of Los Angeles as its case study. This study develops a comprehensive term for sub-centres. They describe that the activity centre is not only defined by employment concentration but also by the trip generation density. The study uses a data series from 1970 to 1990 to study the change of spatial structures in the Los Angeles region. The functional approach is indicated by focusing on how the sub-centres interact with each other. The authors find that a suburban anchor (shopping mall) has a higher trip density than the industrial area that has more employment. This finding means that the existence of a suburban anchor could form a sub-centre and this specification is not based solely on employment concentration. Since the number of subcentres and the job proportion declined each year of their analysis, they state that the Los Angeles region is likely more dispersed than polycentric. These findings differ from the 
results of Giuliano and Small (1991). It also shows that different approaches yield different outputs even in the same case study.

Like Vasanen (2012) and Burgalassi (2010), Cervero and Wu (1997) explain sub-centres from two points of view, by size (morphology) and their functional interaction. Their study focuses on the relationship between sub-centre growth and commuting patterns. Using a given threshold, i.e. seven workers per gross acre and 10,000 workers in sum, Cervero and $\mathrm{Wu}$ identify 22 sub-centres in the San Francisco Bay Area that are stratified into four hierarchical groups or classes based on the employment size. They find that the hierarchical polycentric structure is beneficial to reduce commuting travel by about $30 \%$. This means that a polycentric urban structure can reduce traffic congestion caused by daily trips to work. Furthermore, Cervero and Wu identify a relationship between sub-centre growth and highly segmented housing developments. They describe how new sub-centres stimulate the realestate market in and around employment centres that are most attractive and affordable to professional workers.

McMillen and McDonald (1998) conducted a study about suburban sub-centres and employment density in Chicago. They argue that this research provides two contributions to understanding the causes and effects of suburban employment. Firstly, the force of agglomeration economies influences the establishment of suburban employment. Many firms tend to be attracted to a location which is well served by transportation facilities. Firms gain a cost advantage from being located near to each other, and this may reduce the consumers shopping cost. Secondly, employment density declines significantly with increasing distance to the nearest transportation facilities (rail-lines, highways, and airport). In other words, dedicating more land to transportation facilities would substantially increase employment density. This study points out that transportation infrastructure plays a crucial role in forming urban sub-centres. 
Craig and $\mathrm{Ng}$ (2001) propose to determine an employment sub-centre with a non-parametric method: quantile splines and employment gradient. They use geographically weighted regression and consider the distance to the $\mathrm{CBD}$ to identify the peak of employment density. They argue that this approach is more objective than that of previous studies by McDonald (1987) and McMillen and McDonald (1998). They suggest that this study can also be applied to other locations without the requirement of having specific knowledge about the area. Their research emphasizes the advantages of this approach, in particular its ability to show not just all the highest density areas but also some sub-centres that have a significant influence on their surroundings. Applying the method to Houston, the authors identify seven employment sub-centres which are also the areas for employment.

In another study, McMillen (2001) critiques some procedures for sub-centre identification used in previous studies. McMillen argues that the cut-off points applied by Giuliano and Small (1991), as well as McMillen and McDonald (1998), limit the analysis only to the recognizable metropolitan area. He further contends that the standard linear regression used by McDonald (1987) and Craig and Ng (2001) leads to incorrect centre identification. In his research, McMillen (2001) applies locally weighted regression to the case study area of the city of Milwaukee in the USA. He concludes from this approach that Milwaukee remains in monocentric form. In his article, McMillen also provides significant insights into the benefit of polycentric form for overcoming urban sprawl. He describes how a polycentric urban structure is better than dispersed suburban employment. To cite one example, he argues that if suburban jobs are concentrated in sub-centres, then public transport can be planned to serve the area and workers could reduce their commuting costs.

A different approach was proposed by Yue et al. (2010). They assess polycentricism in Hangzhou, China. Due to a lack of employment data, they use the land use footprint (construction land, cultivated land, forest, and water) as an indicator where data was derived 
from satellite imagery. They analyze the indicator in three steps: (1) directional maps of urban expansion for visually interpreting urban spatial restructuring; (2) urban-rural gradients for analyzing growth along road corridors; (3) growth types to explore diffusion and the combination of urban patches. The values of the average patch (footprint) sizes of urban patches displayed multiple peaks, and the landscape-shape index maintained a horizontal trend in urban fringes, reflecting the formation of polycentricism; the research revealed that Hangzhou has expanded in different directions at various speeds, shifting to a polycentric urban pattern through radial expansion.

The study of Roth et al. (2011) identifies urban centres based on travel flow data obtained from the Oyster travel card in London, whereby individual mobility is considered as a proxy for the activities within an area. They combine the approach of the flow matrix and hierarchical cluster analysis to identify ten important centres that have about $60 \%$ of the total inflow trip. A centre is determined by combining adjacent stations with high total inflow. However, similar to previous studies, their research does not analyze more detailed information about other features that exist in the centers, such as land use.

Zhong et al. (2013) use household travel survey data and apply a centrality index and attractiveness indices to identify urban centres. Density of activities and diversity of land use play an essential role in this study. Zhong et al. use simple probability analysis to combine density and diversity in the same unit that they further develop as a centrality index. The land use features are calculated by diversity measurement. The authors admit that this study needs further investigation to validate the results with the real situation. Moreover, by comparing their findings with the local land use policy they found out that, in general, the results are in line with the land use and transportation planning policies. Nevertheless, they unexpectedly found a new sub-centre that changes Singapore's urban structure and which differs from the local land use plan. 
Fernandez-Maldonado, Romein, Verkoren, and Pessoa (2014) conduct a replication study to case cities in Latin America. They apply a threshold that is similar to the one used by Giuliano and Small (1991) to Mexico City, Lima, and Fortaleza. Even though some data is elaborated from another study, i.e. Aguilar and Alvarado (2005), they provide evidence of the presence of a polycentric urban structure in the three cities..

Cai et al. (2017) propose another method using multi-source geospatial big data. Social media check-in records and night time light data are used as the proxies of human activity areas. Social media check-in data is analyzed by applying a geographically weighted regression (GWR), which delivers possible sub-centres. The analysis considers the distance of sub-centre to CBD. The result is then filtered using natural breaks classification (NBC) to identify the sub-centres. This three step spatial statistical analysis can more accurately identify the boundaries of an urban centre and sub-centres compared to the traditional way of using statistical data of employment which delineates the sub-centre based on the administrative border. The authors define a sub-centre as a set of contiguous tracts with high levels of human activity density and succeed in identifying nine sub-centres in Beijing, twelve sub-centres in Shanghai and eight sub-centres in Chongqing..

\subsection{Inter-urban and national-international scale}

Polycentricism has led to various studies concerning many cases of the decentralized urban area as an approach to examine whether urban expansion has already changed the spatial structure into a polycentric form. Some of these studies also explore the role of old and new centers and the influence of polycentric urban forms on the fields of economics and transportation. From these eight selected articles, one study is from Asia and the remaining seven articles are from European countries (Table 2). 
Table 2. Summary of dominant studies in polycentric assessment at the inter-urban and national-international scale

\begin{tabular}{|c|c|c|c|c|c|c|}
\hline No & Author(s) & Year & Approaches & Indicators & Location & Findings \\
\hline 1 & $\begin{array}{l}\text { Schwanen, } \\
\text { et al }\end{array}$ & 2001 & $\begin{array}{l}\text { Descriptive analysis, } \\
\text { logistic regression } \\
\text { analysis, and } \\
\text { regression model. }\end{array}$ & $\begin{array}{l}\text { Modal choice } \\
\text { Distance } \\
\text { travelled }\end{array}$ & $\begin{array}{l}\text { Urban } \\
\text { Regional } \\
\text { Netherlands }\end{array}$ & $\begin{array}{l}\text { Polycentric form } \\
\text { promotes the use of } \\
\text { private vehicles and } \\
\text { suppresses the use of } \\
\text { public transport, } \\
\text { cycling, and walking. } \\
\text { Polycentric form } \\
\text { results in longer } \\
\text { commuting in some } \\
\text { areas and less } \\
\text { commuting in others. }\end{array}$ \\
\hline 2 & $\begin{array}{l}\text { Riguelle et } \\
\text { al. }\end{array}$ & 2007 & $\begin{array}{l}\text { Local indices of } \\
\text { spatial } \\
\text { autocorrelation } \\
\text { (LISAs) and Kernel } \\
\text { Interpolation to } \\
\text { identify clusters of } \\
\text { employment. }\end{array}$ & $\begin{array}{l}\text { Commuting } \\
\text { flows }\end{array}$ & $\begin{array}{l}\text { Belgian } \\
\text { cities: } \\
\text { Brussels, } \\
\text { Antwerp, } \\
\text { Ghent, and } \\
\text { Liege }\end{array}$ & $\begin{array}{l}\text { Employment remains } \\
\text { concentrated in the } \\
\text { city centres. } \\
\text { Polycentrism is still } \\
\text { weak. }\end{array}$ \\
\hline 3 & Burgalassi & 2010 & $\begin{array}{l}\text { Rank-size } \\
\text { distribution to } \\
\text { measure urban } \\
\text { morphological } \\
\text { polycentricism, } \\
\text { cluster analysis, and } \\
\text { indices of spatial } \\
\text { interaction. }\end{array}$ & $\begin{array}{l}\text { Population and } \\
\text { commuting flows }\end{array}$ & $\begin{array}{l}\text { Tuscany, } \\
\text { Italy }\end{array}$ & $\begin{array}{l}\text { Tuscany can be } \\
\text { viewed as a } \\
\text { polycentric spatial } \\
\text { structure, both } \\
\text { considering rank-size } \\
\text { distribution of cities } \\
\text { and spatial interaction. }\end{array}$ \\
\hline 4 & Vasanen & 2012 & $\begin{array}{l}\text { Spatial cluster } \\
\text { analysis (Moran's } \\
\text { Index). }\end{array}$ & 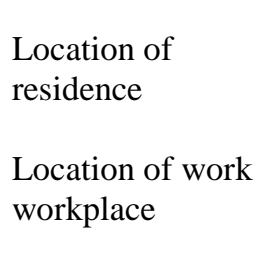 & $\begin{array}{l}\text { Helsinki, } \\
\text { Turku and } \\
\text { Tampere, } \\
\text { Finland }\end{array}$ & $\begin{array}{l}\text { Despite certain } \\
\text { developments towards } \\
\text { polycentricism, the } \\
\text { importance of central } \\
\text { cities is far from being } \\
\text { threatened. }\end{array}$ \\
\hline 5 & $\begin{array}{l}\text { Veneri \& } \\
\text { Burgalassi }\end{array}$ & 2012 & $\begin{array}{l}\text { Rank-size } \\
\text { coefficients and } \\
\text { descriptive statistics } \\
\text { to measure the } \\
\text { morphological } \\
\text { dimension. } \\
\text { Entropy Index } \\
\text { to measure functional } \\
\text { dimension. }\end{array}$ & 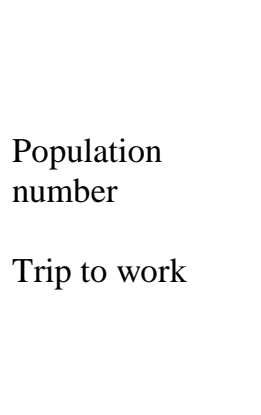 & Italy, Europe & $\begin{array}{l}\text { Functional and } \\
\text { morphological } \\
\text { methods yield similar } \\
\text { results. } \\
\text { Polycentricism has a } \\
\text { strong correlation } \\
\text { between unequal } \\
\text { income distribution } \\
\text { and higher levels of } \\
\text { productivity. }\end{array}$ \\
\hline
\end{tabular}




\begin{tabular}{|c|c|c|c|c|c|c|}
\hline No & Author(s) & Year & Approaches & Indicators & Location & Findings \\
\hline 6 & $\begin{array}{l}\text { Brezzi \& } \\
\text { Veneri }\end{array}$ & 2014 & $\begin{array}{l}\text { Sprawl index to } \\
\text { measure } \\
\text { polycentricism at the } \\
\text { intra-metropolitan } \\
\text { scale. } \\
\text { Rank-size } \\
\text { coefficients and } \\
\text { regression analysis to } \\
\text { measure } \\
\text { polycentricism on a } \\
\text { regional and national } \\
\text { scale. }\end{array}$ & $\begin{array}{l}\text { Population } \\
\text { density }\end{array}$ & $\begin{array}{l}\text { Organization } \\
\text { for } \\
\text { Economic } \\
\text { Co-operation } \\
\text { and } \\
\text { Development } \\
\text { (OECD) } \\
\text { countries }\end{array}$ & $\begin{array}{l}\text { Relatively more } \\
\text { monocentric regions } \\
\text { have higher GDP per } \\
\text { capita than their more } \\
\text { polycentric } \\
\text { counterparts. } \\
\text { At the country level, } \\
\text { polycentricism is } \\
\text { associated with higher } \\
\text { GDP per capita. }\end{array}$ \\
\hline 7 & $\begin{array}{l}\text { Huang, et } \\
\text { al. }\end{array}$ & 2015 & $\begin{array}{l}\text { Potential sub-centres } \\
\text { identified with a } \\
\text { monocentric model. } \\
\text { Polycentric model to } \\
\text { test whether the } \\
\text { candidate sub-centre } \\
\text { fit the research area's } \\
\text { employment } \\
\text { distribution. }\end{array}$ & $\begin{array}{l}\text { Employment } \\
\text { distribution }\end{array}$ & $\begin{array}{l}\text { Beijing, } \\
\text { China }\end{array}$ & $\begin{array}{l}\text { The spatial structure of } \\
\text { Beijing is still quite } \\
\text { monocentric but may } \\
\text { be in transition to a } \\
\text { polycentric pattern. }\end{array}$ \\
\hline 8 & Veneri & 2015 & $\begin{array}{l}\text { Using population } \\
\text { threshold and local- } \\
\text { density peaks to } \\
\text { identify sub-centres. }\end{array}$ & $\begin{array}{l}\text { Population } \\
\text { density }\end{array}$ & $\begin{array}{l}\text { OECD } \\
\text { countries }\end{array}$ & $\begin{array}{l}\text { In specific countries, } \\
\text { there are cities } \\
\text { experiencing a higher } \\
\text { growth in their central } \\
\text { cores, while others are } \\
\text { strengthening their } \\
\text { polycentric structures. }\end{array}$ \\
\hline
\end{tabular}

The research of Schwanen, Dieleman, and Dijst (2001) studies the influence of monocentric and polycentric forms on modal choice and travel distance in the Netherlands. First, the authors classify four types of functional daily urban systems, i.e. central, decentralized, crosscommuting, and exchange-commuting and three types of residential environments, i.e. core city, suburb, and growth centre. Cross-tabulation and logistic regressions are used in the study to analyze modal choice and its relationship with household characteristics, residential environment, and trip purpose. Furthermore, cross-tabulation is implemented to analyze distance travelled against trip purpose, household type, and type of urban system and continued with regression models for work trips. The results show that the polycentric urban 
form promotes driving rather than using a mode of public transport, cycling or walking. This form causes less commuting in some urban regions but longer commuting in others.

Based on employment data, Riguelle et al. (2007) assess medium-sized cities in Belgium (Brussels, Antwerp, Ghent, and Liege) to verify their assumption on whether new sub-centres exist outside the CBD. They use local indices of spatial autocorrelation (LISAs) and Kernel Interpolation to identify clusters of employment. This approach locates local pockets of nonstationary zones and identifies significant local spatial clustering around an individual location. Kernel Interpolation can visualize the concentration of employment. Using these indices, the researchers find that jobs remain concentrated in the primary city centres. The phenomena found in the USA are the opposite of those in Belgium where wages are not getting lower as the centres move closer to the periphery. The small distances between cities in Belgium and the CBD still plays an important role in the economic scale. Riguelle et al. (2007) add that history and the density of urban infrastructure networks are essential.

Burgalassi (2010) performs an assessment in the case of Tuscany, Italy. He assesses the region using rank-size distribution to analyze its morphological polycentricism and spatial interaction indices for functional points of view. This approach considers the intensity of interaction in every centre (node) that he had already found in the morphological approach. Based on this combined method, Burgalassi concludes that Tuscany could be viewed as a polycentric spatial structure by considering the rank-size distribution of cities and spatial interactions.

Implementing a study based on functional polycentrism, Vasanen (2012) focuses on Helsinki, Turku, and Tampere in Finland as case study cities. The degree of polycentricism is measured through the connectivity of the urban centres to the rest of the polycentric urban area with spatial autocorrelation in the Local Moran Index. Commuting data is a primary source in this 
research which interprets the origin as the place of residence and destination as the location of the workplace. Since the data was provided in a high-resolution grid cell, Vasanen uses cluster analysis and cut-off value to identify sub-centres. A significant finding to point out in this research is that, despite certain developments towards polycentricism, the central cities remain important. In other words, polycentric forms are not directly threatening the role of the CBD.

In addition to assessing polycentricism, the following studies also describe polycentric influences in various fields and relating to polycentric form and transportation. Schwanen et al. (2001) divide the Netherlands into four types: one monocentric type and three types of polycentric urban area. Moreover, based on their travel behaviour analysis, they describe how polycentric form promotes the use of private vehicles and suppresses the use of public transport, cycling, and walking.

Veneri and Burgalassi (2012) define and measure polycentricism by comparing functional and morphological methods. Moreover, they investigate the relationships between the degree of regional polycentricism and key economic variables of performance. Since the study is conducted at the regional level, they choose administrative cities as the unit of analysis. They analyze the population distribution by the use of rank-size coefficients. This analysis uses the statistical log-linear distribution principal to define hierarchy which represents the degree of polycentricism. The entropy index is used to measure the node interaction of a given spatial system. Their research finds that functional and morphological methods yield a similar result. Furthermore, the researchers support that polycentricism has a strong correlation between unequal income distribution and a higher level of productivity.

Brezzi and Veneri (2014) measure polycentricism in different spatial structures in OECD (Organization for Economic Co-operation and Development) countries and explore the 
economic implications. They use a sprawl index to measure polycentricism at the intrametropolitan scale and size distribution to measure polycentricism at the regional and national scale. Their findings have a significant influence on the economic field. They conclude that at the regional level, relatively more monocentric regions have higher GDP per capita than their more polycentric counterparts. At the country level, on the other hand, polycentricism is associated with higher GDP per capita.

Unlike the previous studies, Huang et al. (2015) investigate the spatial distribution of employment in Beijing by using a classical method that combines a monocentric and a polycentric model into a customized grid. Firstly, they follow McDonald and McMillen (1990) to identify potential sub-centres and secondly, they build a polycentric model to test whether the candidate sub-centres help explain the overall employment density distribution of the research area. In line with the classical method did, they also consider the distance from the CBD in their model. In conclusion, they describe that Beijing still has a robust monocentric characteristic but is possibly in transition to a polycentric pattern.

In a more recent study, Veneri (2015) examines urban spatial structure on a broader scale. The study takes 29 cities within OECD countries as the study case. Due to the data limitation regarding employment distribution, Veneri uses population threshold and local-density peaks to identify sub-centres. The method does not allow the exact number of sub-centres to be determined but only the number of local units that compose the sub-centres. The results of the study only describe the population distribution across metropolitan and urban areas. Veneri determines that the degree of metropolitan polycentricism increases on average in most OECD countries and suggests that these findings can be of interest to policymakers regarding monitoring the urban population distribution and understanding local needs concerning public service provisions and infrastructure investments. 


\section{Evidence of polycentricism in urban spatial development}

Aside from the methodological insights on how to study polycentricity, the reviewed studies also provide insights on development patterns and underlying factors. They reveal that the trend towards the decentralization of activities has occurred across all world regions where research has been conducted. Cities in North America, Europe, Asia, and Latin America have experienced a similar trend in the transformation of their urban structure. Although some of the studied cities remain in their monocentric structure, many others have moved towards polycentric development (Cervero \& Wu, 1997; Fernandez-Maldonado, 2014; Huang et al., 2015; Riguelle et al., 2007; Yue et al., 2010).

The urban structure of many U.S. cities has changed to a more polycentric form in the last half of the twentieth century (Cervero and $\mathrm{Wu}, 1997)$. Studies show a polycentric structure in the cities of Chicago, Los Angeles, San Francisco, and Houston. These are evidence of the change in urban spatial trends in many U.S. cities due to the decentralization of employment and the advancement of transportation infrastructure (McDonald, 1997; Giuliano \& Small, 1991; Gordon \& Richardson, 1996; Cervero \& Wu, 1997; McMillen \& McDonald, 1998; Craig \& Ng, 2001).

Even though the term polycentricism comes from European country policy, the reviewed studies suggest that polycentricism in some European cities at the intra-urban scale is still weak. Although evidence of polycentricism from England and the Netherlands demonstrates a strong polycentric form, evidence from cities in Belgium, Italy, and Finland show an opposite result (Schwanen et al., 2001; Riguelle et al., 2007; Burgalassi, 2010; Roth et al., 2011; Vasanen, 2012). Furthermore, Le Nechet (2012) describes that many cities in Europe have shifted to a more polycentric form due to the decentralization of activities and increasing 
mobility. The study took 34 cities in Europe, $90 \%$ of the case studies are cities with a population of more than one million.

The studied cities in Asia, especially in China, are also shifting towards more polycentric development. Over approximately the last fifteen years, cities have extended further from the main centre. New agglomerated areas (sub-centres) have developed along a primary transportation corridor. The market forces and planning policy are the two main factors that influence polycentric urban development in China. The planning policy encourages strong decentralization activities and at the same time discourages spontaneous and informal growth (Huang et al., 2015; Yue et al., 2010; Zhong et al., 2013). An interesting observation is that population de-concentration lags behind the urban development process with lower density in sub-centres compared to cities of more developed countries.

Latin America has experienced a similar trend of polycentrism. Many cities are in transition to a polycentric form (Fernandez-Maldonado et al., 2014) but remain in the early stages (Romein et al., 2009). Polycentricism is influenced by job and population decentralization. The changes in manufacturing, commercial, and service locations are linked to the emergence of new sub-centres in the metropolitan areas of Latin America (Fernandez-Maldonado et al., 2014; Romein et al., 2009).

Since the Commission of the European Union (1999) introduced polycentricism as a spatial development guideline, many scholars have claimed that polycentricism has provided less policy contributions, especially on the regional-national scale. According to Rauhut (2017), polycentricism remains a suitable toolbox at the intra-urban scale but requires more evidence at the inter-urban and national scale to deliver the normative concept into the actual balance of regional development. 
A different point of view comes from Veneri and Burgalassi (2012). Based on their study, they suggest that the role of polycentric development in spatial policy should be implemented, more appropriately, at the regional scale.

Based on evidence from studies in Asia, many city authorities have adopted polycentric development as part of their spatial planning policy since early 1990 at the intra-urban scale. Over the long term, this policy has succeeded in containing spontaneous and informal land use development into one that is more concentrated and polycentric (Huang et al., 2015; Yue et al., 2010). Spatial planning policy that adopts the concept of polycentricism has helped local authorities to control their decentralization process. The policy also helps to suppress the disadvantages of spontaneous and informal development, at least in the case of China and Singapore (Huang et al., 2015; Yue et al., 2010; Zhong et al., 2013;). The Asian studies reveal another point of view in polycentricism compared to some studies focusing on a European context alone. For example, Rauhut (2017) argues that polycentricism as policy fails to deliver its political promise and Meijer and Sandberg (2006) found evidence that polycentricism actually increases regional disparities which is a policy failure as well. In Asia, polycentricism as a policy at the intra-urban scale has achieved a successful outcome, according to the reviewed studies.

At the intra-urban scale, polycentricism established a fundamental spatial trend. Polycentricity becomes the remedy for sprawl as the forms of urban sprawl has gradually shifted to a more polycentric form. Polycentricity has become an ideal model to achieve an integrated land use and transport system as it allows for urban centres to develop along with the public transport network. According to some research, polycentric development becomes a model for sustainable urban structure (McMillen, 2001; Newman \& Kenworthy, 2015). 
Polycentricity as spatial planning policy seems more complicated to be implemented on a broader scale, i.e. regional and national (Gløersen et al., 2007). Transnational cooperation is required to achieve the policy's main goal (Faludi, 2004; Faludi, 2005). The benefit of polycentricism as a regional strategy or policies to create a balanced urban system requires more empirical evidence (Wegener, 2013). Other studies have shown that the polycentric form yields longer commuting (Schwanen et al., 2001), lower GDP (Brezzi \& Veneri, 2014), and unequal income distribution (Veneri \& Burgalassi, 2012). Furthermore, a polycentric national urban system has been described as leading to high regional disparities (Meijers \& Sandberg, 2006). Due to the high levels of interaction among centers in the polycentric form, cross commuting that leads to severe traffic congestion might occur (Hoyler et al., 2008).

\section{Research challenges and suggestions for future studies}

This paper reviewed twenty studies concerning polycentricism and urban center identification on the intra-urban and inter-urban as well as on national-international scale. This collection of studies provides not only results on how cities evolve but likewise a summary of the 'state-ofthe-art' regarding the methodological approaches.

From the twelve studies at the intra-urban scale, six studies use statistical analysis while the other six studies use statistical and spatial analysis tools. The statistically based studies consider mainly the cut-off or local peak value to determine the location of a high concentration of employment. The development of a geographical information system (GIS), makes it possible to combine two approaches, i.e. statistical and spatial analysis as shown in the other six studies. This approach can depict other features that exist in the centre neighbourhood, such as availability of transport facilities, type of land use, CBD influences, and so on.

Studies at the inter-urban scale as well as national-international scale show similar 
approaches. Among eight studies, four studies use a statistical approach and four studies use statistical and spatial analysis tools. The focus is to assess whether polycentricism does exist or not and/or to define the polycentric influences on other elements, such as, the use of public transport, cycling, walking, income distribution, gross domestic product GDP per capita or regional growth. This shows that the broader the geographic scale of the studies in polycentricism the less analytical they become. Studies of polycentricism at a larger scale tend to give higher consideration to the relationship of their findings with economic and policy impacts.

An initial challenge that exists is to move towards a more comprehensive understanding of polycentric development and greater evidence of this phenomenon across all world regions. The review demonstrates the very unequal distribution of available studies of polycentricism that have been conducted to-date. These studies primarily exist for cities across the more developed world regions of Europe and North America and, to a lesser extent, to selected and likewise developed (Singapore) and emerging (China) countries in Asia. Studies are limited in Asia and, to our knowledge, not existent for African countries.

A second challenge is the lack of disaggregated and census-based data on employment distribution and travel behaviour as key variables to study polycentricism. While eighteen out of twenty studies use employment distribution and/or travel behaviour as the main variables for assessing polycentricism, they mostly do so in an aggregated form either due to data privacy protection or non-availability. This limits the analysis, e.g. to only larger administrative boundaries or zones and may create bias in the final result.

A third and somewhat connected challenge and way forward is to develop context-sensitive methods and indicators. A polycentricism analysis that relies on well-documented and disaggregated employment distribution and travel behaviour data cannot be applied in cities 
where such data is not available. As an effort to overcome this limitation, two studies included in this review (Cai et al, 2017; Yue et al., 2010) use the land use footprint, night-time light images, and social media check-in as proxy indicators. However, these approaches require a highly sophisticated resolution satellite image and multi-source geospatial big data that are not easily accessible. These studies also require complicated data processing. Another example is that transport supply can be used as a proxy to capture travel behaviour. In many cities in the developing world, however, transport supply is provided informally, and this cannot be captured by 'formal' data like timetables or bus stops. Future studies should consider new indicators that can be easily accessed and processed to yield accurate results of the actual conditions. This will involve the development of indicators that capture local realities. The development of new methods and indicators can overcome the challenge that many cities in developing world region have experienced in assessing polycentricism. These developments will also make it possible to broaden the study of polycentric assessment on the regional-national scale which ultimately requires more evidence, especially for cities in developing world regions.

Finally, studies outside Europe mostly focus at the intra-urban scale. Therefore, future studies should consider assessing polycentricism on the regional and national scale. These studies can bring knowledge on the role of polycentricism as part of planning policy and its economic impact outside Europe. Asia provides evidence of the successful implementation of polycentricism at the intra-urban scale. However, less evidence is found of the success of implementation on the regional-national scale to many regions in the developed and developing world. Future studies should address this issue. Eventually, a comparison of polycentricism and its implementation as a policy on the regional-national scale among cities in Europe, North America, Asia, and Africa should be conducted. This would require the application of the same assessment methodology across cases. 


\section{Conclusion}

This review confirms that studies on polycentricism have, so far, mostly been applied to cities in more developed world regions. The few available studies for cities in developing regions clearly show the difficulties in 'replicating' approaches in the polycentric and urban centre assessment. They likewise point towards the emerging methodological opportunities to use novel proxy indicators and digital-based approaches in the absence of traditional data on mobility and employment distribution.

The reviewed studies demonstrate, for the examined cases, a general shift towards polycentric development. A strong polycentric structure at the intra-urban scale occurred in most cities in the USA, Asia, and Latin America. On the other hand, a robust polycentric structure at the inter-urban scale occurred in cities-regions of European countries. To this point, the implementation of polycentric development as a spatial planning policy outside Europe is only limited to the intra-urban scale. In the more developed world regions, polycentric trends appear to be forced by employment decentralization where many firms are looking for cheaper land value outside the traditional central business district. In cities in developing world regions, the polycentric form is shaped by market forces (e.g., worker migration, demand in housing and services) and, particularly in China, spatial planning policy.

Urban centres or sub-centres have started to develop more complex structures and forms that can be captured not only by the concentration of employment but also by physical features such as land use configuration and street networks. The urban centre cannot be seen only as centres of employment but also as centres of activity, trip attractors or possibly as transport nodes. These definitions enable various indicators to be used to assess urban spatial structure. As discussed, new indicators should be developed to depict the changing roles and functions of urban centres. Due to the greater complexity of urban areas today, employment 
concentration and commuting data are no longer the only variables that form the urban centre. The studies included in this review describe that centre establishment is also influenced by several features, such as, land use type, diversity, distance to the central business district, and distance to transportation facilities (road/highway, stations, rail system). These features are urban physical features and might be possible to use as indicators to identify urban centres. The availability of digital and open source information makes it possible for these features to be captured and used as other proxy indicators as a means to overcome the lack of employment distribution and travel behaviour data that is largely unavailable in cities of the developing regions of the world. The development of GIS tools creates the possibility of examining various potential indicators that can be used to identify urban centres with more simple data processing.

\section{Acknowledgement}

This article is part of the first author's doctoral study program. The first author's gratitude goes to the Indonesian Endowment Fund for Education (LPDP) as the scholarship funder.

Both authors thank the German Aerospace Center (DLR), Institute of Transport Research, for providing the supporting research facilities. We thank Benjamin Heldt at the Institute's Department of Mobility and Urban Development for the valuable input and comments to improve this article substantially.

\section{References}

Aguilar, A.G. and Alvarado, C. (2005). La reestructuracion del espacio urbano de la Ciudad de Mexico; Hacia la metropoli nulti-nodal? in Aguilar A.G. (ed.) Procesos metropolitanos grandes ciudades Dinamicas recientes en Mexico y otros palses, pp.265-308. Miguel Angel Porrua, Mexico, DF. 
Amindarbari R., \& Sevtsuk, A. (2013). Measuring growth and change in metropolitan form. Working Paper: City Form Lab

Brezzi, M., Veneri, P. (2014). Assessing polycentric urban systems in the OECD: country, regional and metropolitan Perspectives. OECD Regional Development Working Papers, 2014/01, OECD Publishing, Paris.http://dx.doi.org/10.1787/5jz5mpdkmvnren

Burgalassi, D. (2010). Defining and measuring polycentric regions. The Case of Tuscany. Discussion Papers del Dipartimento di Scienze Economiche-Università di Pisa, $n$. 101 (http://wwwdse.ec.unipi.it/ricerca/discussion-papers.htm).

Cai, J., Huang, B., Song, Y. (2017). 'Using multi-source geospatial big data to identify the structure of polycentric cities, Remote Sensing of Environment'. http://dx.doi.org/10.1016/j.rse.2017.06.039

Cervero, R., \& Wu, K-L. (1997). Polycentrism, commuting, and residential location in the San Francisco Bay area. Environment and Planning A,Volume 29, 865-886.

Clark, W.A.V. (2000). Monocentric to Policentric: New Urban Forms and Old Paradigms. In G Bridge, S Watson (Eds.), A Companion to the City in, Blackwell, Oxford (pp 141153). Cornwall, UK: Blackwell Publishing.

Commission of the European Union (1999). European Spatial Development Perspective. Towards Balanced and Sustainable Development of the Territory of the European Union.

Craig, S.G. \& Ng, P.T. (2001). Using quantile smoothing splines to identify employment subcenters in a multicentric urban area. Journal of Urban Economics, Volume 49, Issue 1, January 2001, 100-120.

Davoudi, S. (2003). European Briefing: Polycentricism in European spatial planning: from an analytical tool to a normative agenda. European Planning Studies, 11, 979-999.

Faludi,A. (2004). The European spatial development perspective and North-West Europe: application and the future. European Planning Studies, 12:3, 391-408, DOI: 10.1080/0965431042000195010.

Faludi, A. (2005). Polycentric territorial cohesion policy. Town Planning Review, 76(1), 107118. doi:10.3828/tpr.76.1.9.

Fernandez-Maldonado, A.M., Romein, A., Verkoren, O., Pessoa, R.P.P. (2014). Polycentric Structures in Latin American Metropolitan Areas: Identifying Employment Subcentres. Regional Studies, Vol.48,No.12, 1954-1971. 
Giuliano, G \& Small, K.A. (1991). Subcenters in the Los Angeles region. Regional Science and Urban Economics, Vol. 21, 163-182.

GlØersen, E., Lähteenmäki-Smith, K., Dubois, A. (2007). Polycentricity in transnational planning initiatives: ESDP applied or ESDP reinvented? Planning, Practice \& Research, 22:3, 417-437, DOI: 10.1080/02697450701666761.

Gordon, P \& Richardson, H.W. (1996). Beyond polycentricism: the dispersed metropolis, Los Angeles, 1970-1990. Journal of the American Planning Association, 62, 3, 289 295, DOI: 10.1080/01944369608975695.

Green, N. (2007). Functional Polycentricity: A formal definition in terms of social network analysis. Urban Studies, 44(11), 2077-2103.

Hoyler, M., Kloosterman, R.C., \& Sokol, M., (2008). Polycentric puzzles-Emerging megacity regions seen through the lens of advanced producer services. Regional Studies, 42 (8), $1055-1064$.

Huang, D., Liu, Z., Zhao, X. (2015). Monocentric or polycentric? the urban spatial structure of employment in Beijing. Sustainability,7, 11632-11656.

Kloosterman, R.C., Musterd, S. (2001). The polycentric urban region: towards a research agenda. Urban Studies, 38,623-63

Le Nechet, F. (2012). Urban spatial structure, daily mobility and energy consumption: a study of 34 European cities., Cybergeo: European Journal of Geography

McDonald, J.F., (1987). The identification of urban employment subcenters. Journal of Urban Economics,21, 242-258

McDonald, J.F., \& McMillen, D.P. (1990). Employment subcenters and land values in a polycentric urban area: the case of Chicago. Environment and Planning A, 1990, volume $22,1561-1574$

McMillen, D.P. (2001). Polycentric urban structure: The case of Milwaukee. Economic Perspectives $2 Q, 15-27$

McMillen, D.P., \& McDonald, F.J. (1998). Suburban subcenters and employment density in metropolitan Chicago. Journal of Urban Economics 43, 157-180.

Meijers, E., \& Sandberg, K. (2006). Polycentric development to combat regional disparities? The relation between polycentricity and regional disparities in European Countries. ERSA conference papers ersa06p287, European Regional Science Association.

Newman, P \& Kenworthy, J. 2015. The End of Automobile Dependence: How Cities area moving beyond Car-base Planning. Island Press. Washington D.C. 
Rauhut, D. (2017). Polycentricity- one concept or many? European Planning Studies,25:2, 332-338. DOI: 10.1080/09654313.2016.1276157.

Riguelle, F., Thomas, I., Verhetsel, A. (2007). Measuring urban polycentrism: a European case study and its implications. Journal of Economic Geography, 7, 193-215.

Romein, A., Verkoren, O., Fernandez-Maldonado, A.M,. (2009). Polycentric Metropolitan Form: Application of a Northern Concept in Latin America. Metropolitan Form, Autumn 2009, 127-45.

Roth, C., Kang, S.M., Batty M., Barthelemy, M. (2011). Structure of Urban Movements: Polycentric Activity and Entangled Hierarchical Flows. PLoS ONE 6(1): e15923. doi:10.1371/journal.pone.0015923

Schwanen. T., Dieleman F.M., Dijst, M. (2001).Travel behaviour in Dutch monocentric and policentric urban system. Journal of transport geography, 173-186. Pergamon

Schmitt, P., Volgmann, K., Münter, A., \& Reardon, M. (2015). Unpacking polycentricity at the city-regional scale: Insights from Dusseldorf and Stockholm. European Journal of Spatial Development, 59. Available from: http://www.nordregio.se/Global/EJSD/Refereed articles/refereed59.pdf Online publication date: December 2015

Vasanen, A. (2012). Functional polycentricity: examining metropolitan spatial structure through the connectivity of urban sub-centers. Urban Studies 49,16,3627-3644.

Veneri, P. (2015). Urban Spatial Structure in OECD Cities: is Urban Population Decentralising or Clustering?. OECD Regional Development Working Papers, 2015/01, OECD Publishing, Paris.http://dx.doi.org/10.1787/5js3d834r3q7-en.

Veneri, P., \& Burgalassi, D. (2012). Questioning polycentric development and its effects: issues of definition and measurement for the Italian NUTS 2 Regions. Journal of European Planning Studies, Volume 20, Issue 6, 1017-1037

Wegener M. (2013). Polycentric Europe: more Efficient, more Equitable and more Sustainable? Presented at the seminar Welfare and Competitiveness in the European Polycentric Urban Structure: Which Role for Metropolitan, Medium and Small Cities? at the Istituto Regionale Programmazione Economica dellaToscana (IRPET), Florence, 7 June 2013.

You, Y. (2017). The classification of urban systems: a review from monocentric to polycentric. Advances in Economics, Business and Management Research, volume 42

Yue W., Liu Y., Fan P. (2010). Polycentric urban development: The case of Hangzhou. Environmental Planning A. DOI: 10.1068/a42116 
Zhong, C., Huang, X., Arisona, S.M., Schmitt, G. (Eds.). (2013). Identifying spatial structure of urban functional Centers Using travel survey data: a case study of Singapore. In: Proceedings of The First ACM SIGSPATIAL International Workshop on Computational Models of Place, 28-33. Orlando FL, USA 